\title{
Student belonging: Critical relationships and responsibilities
}

Mere Berryman and Elizabeth Eley

University of Waikato, Faculty of Education

\section{Abstract:}

In this paper, we consider New Zealand's education system to understand what can happen when we focus only on excellence and students reaching their potential, without simultaneously investing in their sense of belonging and wellbeing. National statistics suggest we are alienating and shortchanging an increasing number of students and, for disproportionate numbers of Indigenous students, these statistics are part of a world trend. The literature, and the students themselves, highlight the need to overturn the underlying racism that persistently disadvantages clearly identifiable groups of students over others. Until we do, using equity and excellence as the most powerful drivers for reform, will continue to promote conditions where our students' sense of belonging and wellbeing are undermined throughout their education and we will risk, failing to address the ensuing negative statistics. We conclude with a response that we have learned from working with these same students.

\section{Introduction}

The vision statement of New Zealand's Ministry of Education is "to see all children and students succeed personally and achieve educational success" (Ministry of Education, 2016, p.2). We put a great deal of emphasis on ensuring that educational success is reached. Schools' success, as measured by the proportion of students who achieve 'at or above' National Standards and Ngā Whanaketanga Rumaki Māori ${ }^{1}$ (for students in Years 1 to 8), or who achieve a Level 2 award in the National Certificate in Educational Achievement ${ }^{2}$ (for schools with students in Years $11-13$ ) are published for all to judge.

The discourse and the rhetoric that underpins our schooling system, and that is evidenced by the publication of schools' success in promoting academic achievement, is the driver for

\footnotetext{
${ }^{1}$ The achievement expectations for students to meet in reading, writing and mathematics in the first 8 years at school whether they are in English or Māori medium settings.

${ }^{2}$ New Zealand's national secondary schooling qualification
} 
excellence - for all students to achieve to their potential. This discourse leads to a narrowing of the focus of education on academic achievement to the best of a student's ability (excellence); a narrow goal, even when the vision of academic achievement is expanded to include academic achievement for all (equity). What is missing from both the publications of schools' successes and the prevailing rhetoric is reference to how effectively schools are supporting students to become strong and secure in their own language, identity and culture.

However, there is a body of evidence that shows that the education experience of a sizeable and growing proportion of New Zealand students is not a happy one. The Ministry of Education (2016), in the PISA 2015: New Zealand Students' Wellbeing Report, shows that, on the Organisation for Economic Cooperation and Development (OECD) Index of Exposure to Bullying, New Zealand had the second highest average level of all participating countries, with Latvia being the first. The TIMSS 2014/2015 results are consistent with the PISA 2015 results; and show that New Zealand students reported exposure to bullying was higher than in most other participating countries. On the TIMSS bullying scale, 45 percent of students in Year 9 and 60 percent of students in Year 5 reported they had experienced bullying behaviours about monthly or more often (see TIMSS, 2016).

As in other countries, bullying in New Zealand comes in many different forms including racial microaggressions and lateral or horizontal violence. Sue et al. (2007) describe racial microaggressions as derogatory racial slurs directed towards people of color, either intentional or not. Lateral or horizontal violence is described by the Australian Human Rights Commission (2011) and others, as bullying and intimidating behaviors that are directed against one's peers rather than their true adversaries. This means aggressive behaviors such as gossiping, bullying, shaming, social exclusion and even physical violence, can come from one's own social group. Lateral violence is often experienced by Indigenous people in colonized countries. This has relevance when we consider the power imbalances within our schools. Fundamentally, when our systems continue to engender feelings of powerlessness, people who feel oppressed take their frustrations out on each other because they feel powerless to confront the system.

The Ministry of Education report the results from the measuring of students' sense of belonging at school in the 2015 PISA assessments. Since 2003, New Zealand students have 
reported a weakening sense of belonging. There has been an increase in the percentage of students who reported they felt like an outsider (or left out of things) at school: from 8 percent in 2003 to 22 percent in 2015. Students' sense of belonging weakened on average across the OECD, but to a lesser extent than in New Zealand (Ministry of Education, 2016, p.18). Across New Zealand Schools, between 17 and 22 percent reported that at school they felt:

o like an outsider or left out of things;

o awkward and out of place; or,

o lonely (ibid. p.18).

This evidence sits alongside an even greater concern, that of New Zealand's high rate of youth suicide. A UNICEF report from June 2015, using a set of internationally agreed criteria, ranked New Zealand at the bottom of the 41 European Union and OECD countries in the "Good health and wellbeing" category (UNICEF Office of Research, 2017, p.21-22). The report drew attention to New Zealand's high adolescent suicide rate - at 15.6 youth suicides per 100,000 people, New Zealand had the highest youth suicide rate of all the 41 countries, and within these statistics, Māori are disproportionately overrepresented.

Our education system has continued to become more highly focussed on the excellence of achievement outcomes of our youth, and yet, as demonstrated in the 2015 PISA results, while around $83 \%$ of New Zealand students perform at the level expected for their age (see May, Flockton \& Kirkham, 2016), we continue to see up to 20 percent of our students performing below their expected level. As these negative statistics continue to grow, and this is especially so for Māori, it appears that we may not be paying enough attention to our students' sense of belonging and wellbeing.

\section{'Belonging' as a foundational education principle}

New Zealand's early childhood curriculum - Te Whāriki - is underpinned by the vision that children "are competent and confident learners and communicators, healthy in mind, body and spirit, secure in their sense of belonging and in the knowledge that they make a valued contribution to society" (Ministry of Education, 2017, p.5). This vision statement shows the importance placed on learning, on holistic wellbeing (healthy in mind, body and spirit) and on a sense of belonging - with an implicit reference to acknowledging that even very young 
children can both give and receive within our society. Belonging is one of the "five areas of learning and development in which the focus is on supporting children to develop the capabilities they need as confident and competent learners" (Ministry of Education, 2017, p.16). This positioning reinforces the centrality of the notion of belonging as being foundational to learning and a significant contributor to ongoing and lifelong learning. The curriculum vision statement for students in the New Zealand compulsory schooling years (typically aged from five years old to about 18 years old) does not put the same emphasis on the students' sense of belonging. The New Zealand Curriculum vision statement is for young people "who will be confident, connected, actively involved, and lifelong learners" (Ministry of Education, 2007, p. 8). While the reader of the New Zealand Curriculum and this statement can assume that a sense of belonging is required to reach the vision, this is left implicit within the curriculum. The notion of belonging remains hidden through the curriculum statements of vision, principles and values and does not become explicit until reference is made within the discussion of the five key competencies - the fifth one being "participating and contributing", where we are told that "students who participate and contribute in communities have a sense of belonging and the confidence to participate within new contexts" (p. 13). This is the first explicit reference within the compulsory schooling curriculum to a concept that is seen as foundational to New Zealand's early childhood curriculum.

An unrelenting focus on academic achievement may be desirable and even laudable within the state-funded education system. However, a focus only on equity and excellence, without a corresponding focus on belonging, closes down discourses that open other ways of thinking and being. There is a lost opportunity to explore a broader view of education that opens discussions and foci on "belonging, being, and becoming" - concepts that underpin the Early Years Learning Framework for Australia and are the descriptions raised by McLaren in Berryman, Nevin, SooHoo, and Ford (2015b, p. xiii) as an alternative framing for schooling. In addition, the relentless focus solely on academic excellence and equity can have severe and ongoing consequences for our students - particularly those who are seen to be located outside of the dominant, mainstream society.

As Berryman et al (2015b, p.1) state, education systems, including the New Zealand system, are becoming more culturally, ethnically and linguistically diverse. However, we are see a 
significant proportion of our students outside the dominant culture who are "marginalized, [as they] watch from the edges, often feeling belittled, othered and/or alienated" (ibid. p.2). It is challenging for students from Indigenous and minority cultures to live their own culture and speak their own language when it is surrounded and overpowered by another more powerful culture and language (Berryman, 2008). And, what racially micro-aggressive messages are we sending when we hear (in an election promise by the incumbent government), that students will be able to learn a second language, when the two official languages of this country, sign and Māori, are listed ninth and tenth on the list of ten suggested second languages - the first eight being foreign languages? Given, of course, that in the midst of this diversity, students who have learning and/or physical disabilities can be further problematized and excluded.

\section{What is 'belonging'?}

Belonging is the way in which people feel accepted, respected, included and supported by a community in which they are involved (Watson, 2005). The need to belong has been identified as a fundamental human motivation, taking precedence in human need over selfesteem and self-actualization (Baumeister \& Leary, 1995). These authors further argue that belonging is a powerful influence on human thinking and "both actual and potential bonds exert substantial effects on how people think" (p. 505).

A sense of belonging has clear implications for the social experience of students, and plays a crucial role academically. Goodenow $(1993$, p. 80$)$ describes 'belonging in school' as melding the concepts of belonging and connectedness, whereby children feel accepted, respected, included, and valued by others. When students feel they belong in school, there is an increase in participation and learning; along with less fear of judgment from other students or the teacher (Watson, 2005).

There has been considerable investigation into students' 'sense of belonging at school', as school is central to the daily life of almost all young people. An OECD report investigated Student Engagement at School. In this report, a student's sense of belonging or attachment to school, is described as a psychological component to do with "feelings of being accepted and valued by their peers, and by others at their school". A further component is whether or not students value school success - do they believe that education will benefit them personally and economically (see Johnson, Crosnoe, \& Elder, 2001, p.318). When this sense 
of belonging is strong, students "view schooling as essential to their long-term well-being", and is demonstrated through their participation in academic and nonacademic pursuits (Willms, 2003, p.1) and positive "relations with school staff and other students" (Willms, 2003, p. 8).

A sense of belonging has considerable impact on students' subsequent performance at school and is "central to both their psychosocial well-being and their academic success" (Chiu, Chow, McBride, \& Mol, 2016, p.175). For example, Baumeister, Twenge and Nuss (2002) outline the positive relationship between social connectedness and cognitive performance and Walton, Cohen, Cwir and Spencer, (2011) add that "the mere sense of social connectedness" enhances students' motivation to achieve, as they respond to and quickly adopt the goals of others as their own, within a group environment (p. 529). A review of the literature shows that adolescents with a greater sense of belonging at school often show higher academic performance, higher intrinsic motivation, and more positive attitudes toward schooling (e.g., Anderman, 2003; Gonzalez \& Padilla, 1997; Goodenow, 1993; Roser, Midgely, \& Urdan, 1996). Furthermore, students with higher sense of belonging at school generally have fewer psychological health and social problems, specifically: lower rates of delinquency; reduced social rejection from peers; lower depression; fewer incidences of dropping out of school; and, less use of illicit drugs (Anderman, 2002; Finn, 1989).

Factors that affect student perceptions of belonging include connection with teachers and peers and participation in school activities (Wallace, Ye, \& Chhuon, 2012). A teacher can facilitate the perception of belonging by encouraging each student to know that they are valued and have a role within their community, helping them to find their niche (Strahan, Smith, McElrath, \& Toole, 2001). The onus is on our educational structures to "identify and empower the diverse voices in our classrooms to share their ways of knowing and know that they will be respected in that environment, [to] foster communities of learning and feelings of belonging - ... a state of mind linked to trust, faith, humanity, community, and social justice" (Berryman et al., 2015b, p.159).

\section{Belonging and Inclusion}

In this paper, we extend Watson's (2005) definition of 'belonging' to define a sense of belonging at school to mean the way in which students feel accepted, respected, included 
and supported by the educational communities and settings in which they are involved. In this we are focusing on what the literature, such as that outlined above, describes as the psychological component of feelings and connectedness. We hold this as distinct to a parallel term 'inclusion'. The New Zealand, Ministry of Education's inclusive education website describes a 'fully inclusive school' as one where:

"all students are welcome and are able to take part in all aspects of school life. Diversity is respected and upheld. Inclusive schools believe all students are confident, connected, actively involved, lifelong learners and work towards this within the New Zealand Curriculum. Students' identities, languages, abilities, and talents are recognised and affirmed and their learning needs are addressed" (Ministry of Education, 2010).

In some research and literature, the two concepts - belonging and inclusion - are used almost interchangeably. We have chosen to keep these terms as distinct - using the term 'belonging' for the internalized concept and response to schooling by the student and the term 'inclusion' to describe the policies, actions and decisions taken by those (usually the adults) within schools in an effort to bring all young people into the learning experiences.

\section{Belonging at School for students of Indigenous and minority cultures}

Our education systems are becoming more culturally, ethnically and linguistically diverse, but, "rather than benefitting from and learning from each other, we continue to expect our students to be represented within the same curriculum, pedagogy and testing regime or we form separate enclaves and the divide becomes even wider" (Berryman et al., 2015b, p.1). We do our students no favors when we continue to perpetuate the myth that the experience of one is the experience of all. When the notion of belonging at school has been posited as having the same meaning and influence on educational experiences for all students then we are in danger of missing or trivializing the experiences for "those who are marginalized, watch from the edges, often feeling belittled, othered and/or alienated" (Berryman et al., 2015b, p.2). Murphy and Zirkel $(2015$, p.3) identify what they call 'salient concerns' about belonging in school because some students' social identities make them vulnerable to "negative stereotyping and social identity threat-the threat that one's social group may be devalued in a particular setting" (see also Steele, Spencer, \& Aronson, 2002). 
In a large longitudinal study conducted in the United States, Murphy and Zirkel found that there were concerns expressed by White students about whether they would fit in socially. However, they found that there was an "academic impact on students' actual feelings of belonging in their current educational contexts only for the group identified as stigmatized students of color" (Murphy \& Zirkel, 2015, p.28). They attribute this pattern of findings to a concept described by Walton and Cohen $(2007,2011)$ as 'belonging uncertainty'. Walton and Cohen pose that educational institutions are 'raced', that is, that "students, and even some teachers, associate the institution of education ... as a White enterprise" (see, for example, Gillborn, 2008; Lee, 2005; Lee, 2011; Leonardo, 2010). Murphy and Zirkel conclude that there is an implied degree of belonging for White students in educational settings. However, they go on to say that, even in academic settings in which students of color make up a majority of the student body, "because the institution of education is raced in ways that favor White students, experiences of belonging may be more informative and diagnostic of their standing in school for students of color than for White students" (p.28). These findings are very much in line with the role of racism in impacting on students' school experiences as outlined by Peter McLaren in the preface to Relational and responsive inclusion: Contexts for becoming and belonging (Berryman et al, 2015b, p. xv). McLaren reminds us that we don't need to be racist (i.e. belief in the overall inferiority of certain racial groups) to be complicit in racist practices, as racism "can also be embedded in 'structures' that themselves carry the historical legacy of violence against minoritized populations". He states that our actions (often unwittingly) conform to rules, codes and practices that disadvantage certain groups (notably minority student groups) and privilege others. In New Zealand, we would suggest that this has implications for both those that are disadvantaged (typically our Māori students) and those that are more privileged - typically the non-indigenous, Pākehā New Zealanders.

Evidence presented by the Ministry shows that there is a persistent and ongoing disadvantage for Māori students within our schooling system. A number of different analyses across the best evidence syntheses (Alton-Lee, 2003; Biddulph, Biddulph, \& Biddulph, 2003; Mitchell \& Cubey, 2003; Timperley, Fung, Wilson, \& Barrar, 2006) revealed that New Zealand's education system performance has been inequitable for Māori learners, citing the following contributors: 
- low inclusion of Māori themes and topics in English-medium education,

- fewer teacher-student interactions,

- less positive feedback,

- more negative comments targeted to Māori learners,

- under-assessment of capability,

- widespread targeting of Māori learners with ineffective or even counterproductive teaching strategies (such as the 'learning styles' approach),

- failure to uphold mana ${ }^{3}$ Māori in education,

- inadvertent teacher racism,

- peer racism,

- mispronounced names.

This evidence is cited as background information for the Māori Education Strategy: Ka Hikitia - Accelerating Success, described by the Ministry as "our strategy to rapidly change how the education system performs so that all Māori students gain the skills, qualifications and knowledge they need to enjoy and achieve education success as Māori" (Ministry of Education, 2015, P.5). On their Ka Hikitia website, the Ministry also report the conclusion drawn by internationally renowned Harvard professor, Courtney Cazden, who, in 1990, after working with teachers in New Zealand, highlighted how deeply entrenched such disadvantageous, differential treatment is within the beliefs and practice of many New Zealand teachers. In most cases, this is not conscious prejudice, but part of a pattern of well-intended but disadvantageous treatment of Māori students.

\footnotetext{
${ }^{3}$ Mana is a concept within Māori culture that represents a supernatural force in a person, place or object. There is no direct translation in English, as it encompasses aspects of prestige, authority, control, power, influence, status, spiritual power, and charisma.
} 


\section{What are our students' experiences?}

Up until this point, we have drawn from research and literature to make the following cases, that:

- in order to achieve our educational vision of all students reaching their potential, we must pay as much attention to the concept of belonging as we do to the drivers of equity and excellence; and,

- woven into the very fabric of our educational system is an underlying racism that persistently and perniciously disadvantages Māori students.

While the research and literature provide a compelling argument, even more compelling are the stories of our students who have related their ongoing experiences of marginalization and alienation. Students' stories have been told and relayed over a considerable period of time. We report here on themes from students' own narratives between 2001 and 2015.

Year 9 and 10 Māori students: 2001

In 2001, student experiences were gathered in conjunction with the introduction of Te Kotahitanga ${ }^{4}$. Participants within five school communities were interviewed. These included the principal, teachers, whānau members and students who were identified by the schools as being engaged in learning and those not engaged in learning. The themes from these students' experiences are summarized within Culture Speaks (see Bishop \& Berryman, 2006, p.254-5).

For Māori students, both those identified by their schools as engaged and those as not engaged, being Māori in secondary school was a negative experience (p.254). These students were very aware of negative stereotypes about Māori. They believed that many teachers overtly negatively-stereotyped Māori students, with some teachers being covertly racist. They felt that teachers expected them to misbehave and were constantly looking for misbehavior (and finding misbehavior that would be ignored in other students) and, likewise, teachers ignored opportunities to recognize good behaviors. Despite this, students had high expectations of schooling and teachers and had high aspirations for their own

\footnotetext{
${ }^{4}$ Te Kotahitanga (Unity of Purpose) was an iterative school reform initiative that emphasised the crucial importance of culturally responsive and relational pedagogies if Māori students were to engage with learning and have their language, culture and identity valued and respected within the system. (Bishop, Berryman, \& Wearmouth, 2014).
} 
achievement towards gaining employment and contributing to their whānau. The authors concluded that "despite reporting that their experiences in education were overwhelmingly awful, year after year, these students understood and were still optimistic about the possibilities that education offered them" (Bishop \& Berryman, 2006, p.255).

Secondary school Māori students from 2005 - 2009

Between 2005 and 2009, as part of Te Kotahitanga Phases 3, groups of students from 12 different schools were interviewed. Again, students recalled moments within their schooling that held promise. However, their experiences continued to be set against a background of racial microaggressions (Sue et al. 2007) or lateral violence that continued to belittle their own identity, language and culture.

Successful senior Māori students from Kia Eke Panuku 2015

Our 2015 voices are drawn from the 158 Māori students interviewed as part of a series of nine hui (meetings run following Māori cultural procedures) hosted by the Kia Eke Panuku team. Held on marae (iwi cultural spaces) across New Zealand, the hui occurred after the completion of the 2015 school year. Up to three successful, senior Māori students were nominated by their school ${ }^{6}$ and accompanied by one adult from the school. Most frequently the adults involved a member of the school's Senior Leadership Team but also included teachers, whānau (family) and iwi members.

The 2015 students were more positive than their 2001 and 2005-2009 counterparts. This is not surprising. These students attended schools committed to making an accelerated difference for Māori students as evidenced by their willingness to participate in Kia Eke Panuku: Building on Success. These students were also successful students, most of whom had completed their secondary schooling through to the final year (Year 13) and they had gained qualifications for entry to (some already had been accepted into) tertiary institutions. They were very aware, though, that their stories, did not represent the experiences of all their Māori student peers, even those in their own schools.

\footnotetext{
${ }^{5}$ Kia Eke Panuku: Building on Success was a school reform initiative operating in 93 secondary schools across New Zealand. The kaupapa (central purpose) of Kia Eke Panuku was: Secondary schools giving life to Ka Hikitia and addressing the aspirations of Māori communities by supporting Māori students to pursue their potential.

${ }^{6}$ Fuller details on the nomination and confirmation process are provided on the Poutama Pounamu website: https://poutamapounamu.org.nz/student-voice/about-the-themes/collated-quotes-gallery
} 
Detailed thematic analysis of the messages from the hui are presented as nine themes on the Poutama Pounamu website ${ }^{7}$. Overall, the messages from the students are strongly inter-related. The most compelling message from these students was that to be successful as Māori within the school system, they had to be able to resist and overcome other people's low expectations and negative stereotypes about them being Māori. Some Māori students directly attributed their success to the support they had received from a school environment - where their own culture and values were explicitly celebrated, modelled and thus made more acceptable by and for both Māori and non-Māori. This was essential to being able to be strong as Māori, rather than believing they had to compromise their own cultural identity by trying to pass as someone else. Understanding that success was a part of who they were and what other Māori were, or could be, required their being emotionally and spiritually strong. These students understood that at times this had not been the case for them, nor was it the case for many of their peers, including those friends and whānau some of whom, a number shared, had resorted to suicide, the absolute extreme reaction to feelings of not belonging.

\section{Aligning the literature and student stories}

\section{Students' views on contributions to their sense of belonging}

We have drawn from the very generic definition of belonging as proposed by Watson (2005, p.47) who said that a person experiences a sense of belonging when they "feel accepted, respected, included and supported by a community in which they are involved". We broadened this concept to encapsulate the notion of belonging at school to mean the way in which students feel accepted, respected, included and supported by the educational communities and settings in which they are involved. In addition, Wallace, Ye, and Chhuon (2012) have referred to the connection with teachers and peers and participation in school activities as being essential in contributing to one's sense of belonging.

Within our interviews, some Māori students were able to point to times when they felt accepted, respected, included and supported by their schools and their teachers. This was more prevalent in 2015 - which is to be expected as these schools had made deliberate

\footnotetext{
${ }^{7}$ https://poutamapounamu.org.nz/student-voice
} 
efforts to implement Kia Eke Panuku - a whole school reform program based on a kaupapa or agenda of Māori succeeding as Māori. The students were able to say things such as:

- We have a strong sense of what it is to be Māori within our school. (2015)

- I'm really interested in history, but when I look back and think of the intergenerational hardship our grandparents and our ancestors who are Māori have had to deal with since the Treaty and the New Zealand wars, that inter-generational cycle of hardship that they've had to overcome and endure, I think how lucky I am and how lucky we are. We have the opportunity to take on different experiences and can go to school where there are teachers who are supporting us. That we can be proud to experience our culture, rather than being punished for it like our grandparents were so long ago. I think how lucky we are to enjoy success as Māori, and for that success not only to be for ourselves, but for the collective, for our whānau, for our village. (2015)

- All the teachers, instead of just saying: "Stand up!", they'll say: "E tu!". And instead of saying: "Sit down!", they'll say: "E noho!". And they're using those small Māori sentences and scenarios to be able to make the classroom a friendlier environment for Māori students. (2015)

In 2001 and 2005-2009, some students reported steps made by some teachers that demonstrated their acceptance, respect and support for Māori culture and values. However, these were more likely to be described as isolated incidents within the school, rather than the sense of relationships of trust and respect and a culture of care across the school and into the home community.

- Something that helps students get along is having a good teacher, like a teacher you respect and get along with. You like and respect them, and they like and respect you. (2001)

- The teacher I liked best wasn't Māori but he could have been. He knew all about our stuff. Like, he knew how to say my name. He never did dumb things like sitting on the tables ... We always planned our lessons together. He was choice. (2001) 
- When one teacher I know taught the class, even if one Māori didn't get it, she wouldn't move on until everyone got what she was trying to say. She understood Māori things. (2001)

A sense of belonging at school comes from other students. However, our students tell us that we also need to draw from the cultural toolkits of family and whānau, and from community members.

- Sometimes the people that help you succeed are the people that don't really realize that they're doing it. Like people that you look up to as role models so that you want to emulate what they're doing. It gives you courage to be better than what is expected of you. (2001)

- We have got quite a few Māori students, but she is the only quite brown one and she feels quite left out by that. But, just recently, we have got another Māori student. She feels better having someone else there. (2001)

- This year our top academic students were both Māori, and I think that it just drove us all. (2015)

- Not only do our teachers help us, but our kaumātua help us learn - we should also embrace our connection with our kaumātua. (2015)

- I've succeeded because I've had the help of others. Doing it on your own is just not easy, so having those others there, helping you, is essential. (2015)

Our 2015 students also talked of how having activities that built on Māori culture helped affirm their sense of belonging at school.

- We have a culture to be proud of. Kapa haka is amazing. It makes your blood boil. It makes your eyes open. It's just amazing. (2015)

- With the Mãori culture, there's something that you can just own. You don't have to be afraid to be yourself. Even though some Māori don't do kapa haka (cultural performances), some don't do certain things, you still are Māori. You carry pride, you carry mana, and you're still part of something that is really cool. (2015)

- It's achieving academically, in sports, and in a range of different areas - but still holding on to your culture and who you are as Māori, and what it means to be Māori. (2015) 


\section{Students' views on detractors from their sense of belonging}

As the literature shows, there are particular challenges around a sense of belonging at school for those whose "social group may be devalued in a particular setting" (Steele, Spencer, \& Aronson, 2002, p.381), or, whose "social identities make them vulnerable to negative stereotyping and social identity threat" (Murphy and Zirkel, 2015, p.3). Murphy and Zirkel also identify the particular effect on students who are "stigmatized students of color" (2015, p.28).

Our students in the earlier interviews were very clear that racial microaggressions were rampant in their school experiences and they viewed this as explicit racism:

- Some teachers are racist. They say bad things about us. (2001)

- Well, some people just don't like Māori much. It's pretty good here. There are only two teachers that make racist comments. One of these told me when I was a Form 2 kid [the year prior to entering secondary school] that he would sort out my black head when I came to high school, so I'd better watch out. (2001)

- [My friend] was doing something, not quite what she should have been doing but there were others with her and the teacher said to her "you are just a typical Māori". (2001)

In 2015 students were very clear that they faced ongoing pressure from stereotypes about Māori that played out as racial microaggressions and lateral violence:

- People saying stuff like: "Māori can't do this, can't do that" - it's just heart-breaking, because we do have a lot of Māori achievers within New Zealand. It's really good knowing when you have done something and you've done your culture proud. (2015)

- People in our community say, "Oh, that person's dumb because they're Māori". Being a school leader next year, I will work against this stereotype that Māori are underachievers. It's a privilege, and I hope that other Māori students and our community can realize that. Just because you're Māori, it doesn't mean that you're dumb. And it doesn't mean that you can't achieve. 
- If you're a Māori, you're probably already put in those classes where they're not pushing you to succeed as much, so automatically you do not achieve well. That's the overall stereotype of Māori achievement. People aren't expecting as much of you. (2015)

- It means there's hope for Māori to become something more than everyone's stereotypes. It brings hope just to see that we can actually make a difference. (2015)

While these students had worked hard to overcome these acts of bullying and violence, they knew that many others of their peers were not as resilient.

\section{Mauri ora}

While the experiences of many students from across these research settings revealed that for some, the education experience was "overwhelmingly awful" (Bishop \& Berryman, 2006, p.255), others, especially the students from 2015 , had found the means and the support needed to flourish within their schools. Sometimes, this was because of the actions of those charged with providing their education and, sadly, at other times it was despite the actions of their educators. We have referred to the flourishing within schooling as being linked to the concept of mauri, where one's life force or inner essence is in a state of ora (flourishing and strong). Whilst this concept has layers of meaning, we draw on the theorizing of Sir Mason Durie. Durie (2014) suggests mauri ora is demonstrated when a person is engaged in positive relationships with others, is spiritually and emotionally strong, is positive and energetic, and feels a sense of belonging. Māori students told us:

- Being a successful Māori means a real strengthening of identity. The more we succeed, the more we identify with who we are, which resonates with where we're from, and obviously, we're Māori. (2015)

- $\quad$ By succeeding we give more power to our people, to our culture. It just means being able to grow, become bigger and spread our wings to other people, other Māori. And it's just really, really cool. (2015)

The students in 2015 described a simultaneous success trajectory; that when their cultural identity was strong and secure and they were learning and achieving for the future then equity, excellence and belonging was possible. For these students, success enabled them to walk confidently and with mana (ascribed power and authority), in the two worlds of 
Aotearoa New Zealand, Māori and non-Māori. When students are flourishing within our schools, when they feel that they are at home and at ease with the systems and structures and are achieving to their potential, then they are understood to be in a state of mauri ora. However, when the student is not flourishing and their family background is not celebrated and valued, but is languishing within the system, then (again using the terminology of Durie) the student can be described as being in a state of mauri noho. In this state, students are unable to rise above the factors that erode their sense of belonging at school and their ability to reap the benefits of their education. Students are unable to engage effectively with their learning. This poses a particular challenge for schools and for teachers who develop 'student-centered' learning opportunities and programmes. Although wellintentioned, student-centered programmes will not benefit a student who is languishing students who do not have a sense of belonging at school, who are not flourishing within the school environment, are likely not to reach their potential. The student in the center of 'student-centered programs' must be flourishing, they must demonstrate the factors of mauri ora identified by Durie: that is, be engaged in positive relationships with others, be spiritually and emotionally strong, be positive and energetic and they must have a sense of belonging.

\section{Activating agency}

To bring this about, we require what Glynn (in Berryman et al, 2015b, p.29) calls a "radical transformation in teaching, in teacher education, and [this] involves all education personnel accepting collective responsibility for the education of all their students". In short, we require a radical re-culturing (Carrington \& MacArthur, 2012) where, through attention to both cultural relationships and responsive pedagogy, we promote a new culture across the school that builds rather than erodes the students' sense of belonging. Developing cultural relationships within which to embed responsive pedagogy has been shown to make these contexts for learning possible with ensuing statistically significant advantage for students (Alton-Lee, 2015).

\section{Cultural Relationships for Responsive Pedagogy}

The concept of Cultural Relationships for Relational Pedagogy grows out of two decades of theorizing, research and praxis. Māori students first collaborated with researchers to develop 
a culturally responsive home school behavioral program in 1996 (Berryman \& Glynn, 2004). Then in 2001, within the Te Kotahitanga initiative, Bishop and Berryman (2006) used the voices and experiences of Māori students to define an Effective Teaching Profile. It was found that when teachers implemented this profile in classrooms, they enacted a culturally responsive pedagogy of relations. This was defined as a pedagogy where contexts for learning promoted:

- power sharing;

- a focus on the students' culture;

- interactive and dialogic learning;

- relational connectedness;

- a common vision of excellence for Māori in education.

Ongoing research throughout Te Kotahitanga, and further theorizing and implementation through Kia Eke Panuku, led to a refining of the concepts underpinning the culturally responsive pedagogy of relations. To support teachers to focus on both components, Cultural Relationships and Responsive Pedagogy, a model where both components were explicitly interdependent was developed. Fundamental to this is the understanding that learning is not simply linked to relationships between people but learning is deeply embedded in the types of relationships that exist between ourselves, our learners and their families and that these relationships are often deeply embedded in one's own culture.

Cultural relationships require us to create spaces in which we must first listen to our students and their communities. Such spaces open the opportunity for the sharing of prior knowledge and experiences, identities, aspirations, concerns and connections (Berryman et al, 2015b). They also allow each individual to determine whether they will engage in the dialogue or not. This points to the importance of trust and respect and the need to understand that developing such relational dialogic spaces (Berryman et al, 2013; Berryman et al, 2015a) takes time and commitment.

Cultural relationships benefit from our engagement with mana ōrite, a Māori metaphor that acknowledges inter-dependent relationships that bring responsibilities to each group to maintain the mana or personal prestige of the other. A relationship in which the mana of 
the other is treated as ōrite (alike, similar, identical or equal); or, as many students have said "respect me, like they want me to respect them." In the English language, such a relationship has often been translated as a 'partnership' and, in reality, the parameters of this partnership have continued to be defined by the majority partner. The role school leaders and teachers have in understanding and perpetuating or disrupting this thinking, is essential.

On the basis of such relationships, responsive pedagogy can then begin to incorporate a wide range of information including what you know and are still learning about the students' own cultural contexts. More importantly, are opportunities for the students to apply their own prior knowledge and experiences, what they have in their own "cultural toolkit" (Bruner, 1996), as the basis for determining their next learning steps. This one size fits one approach to personalizing learning begins with active listening so that the listener is as actively engaged as the speaker in seeking to make sense of what is being constructed. It requires the listener to be attuned to both verbal and nonverbal messages, to defer judgement, and to formulate their response only when the speaker has finished. Asking students for their ideas and questions about the learning contexts and being prepared to act accordingly promotes opportunities to take reciprocal responsibility to learn from and teach each other. This is further strengthened when we also find ways to take advice and learn from and with the students' own homes and communities in order to define and achieve common outcomes.

\section{Conclusion}

The literature, and the students themselves, highlight the need to overturn the underlying racism that persistently disadvantages clearly identifiable groups of students over others. Attention to the racial microaggressions and lateral violence experienced by many of our students is a priority. However, if we also continue to champion visionary statements about all students 'reaching their potential', then impose a mono-cultural curriculum and evaluation regime in the name of equity and excellence, we will continue to see some students succeed but risk ongoing alienation of other groups within our student populations. Schools' perpetuation of a situation where some students succeed and others fail, might at best be interpreted as racial microaggressions. From these students, we heard examples of the lateral violence that this situation promotes. 
As educators we must also focus on our students' sense of belonging and wellbeing within the education system and we must find more effective ways to include the families of these students in the learning conversation. This can be achieved with a clear focus on a relational and responsive pedagogy, when it comes from a place in which we as educators, believe in and enact our ability to affect change in our society through the realized potential of the students who we work alongside, for they are our future leaders. 


\section{References}

Alton-Lee, A. (2003). Quality teaching for diverse students in schooling: Best evidence synthesis. Wellington : Ministry of Education.

Alton-Lee, A. (2015). Ka Hikitia Demonstration Report: Effectiveness of Te Kotahitanga Phase 5 2010-12. Wellington, NZ: Ministry of Education.

Anderman, E. M. (2002). School effects on psychological outcomes during adolescence . Journal of Educational Psychology, 94, 795-809.

Anderman, L. H. (2003). Academic and social perceptions as predictors of change in middle school students' sense of school belonging. Journal of Experimental Education, 72, 522.

Australian Human Rights Commission. (2011). Social justice report 2010. Sydney: Australian human Rights Commission.

Baumeister, R., \& Leary, M. (1995). The need to belong: Desire for interpersonal attachment as a fundamental humna motivation. Psychological Bulletin, 117(3), 497-529.

Baumeister, R., Twenge, J., \& Nuss, C. (2002). Effects of social exclusion on cognitive processes: Anticipated aloneness reduces intelligent thought. Journal of personality and social psychology, 83(4), 817-827.

Berryman, M., \& Glynn, T. (2004). Hei āwhina mātua: The development of a New Zealand bicultural home and school behaviour management programme. In J. Wearmouth, $T$. Glynn, R. Richmond, and M. Berryman, (Eds.), Inclusion and Behaviour Management in Schools: Issues and Challenge (pp 240-262). London: David Fulton Publishers in association with the Open University and the University of Waikato.

Berryman, M., Nevin, A., Soohoo, S., \& Ford, T. (2015a). A culturally responsive framework for social justice Information Age Publishing, Inc. In M. K. Esposito, \& A. H. Normore, Inclusive practices and social justice leadership for special populations in urban settings: a moral imperative (pp. 143-164). Charlotte, NC: Information Age Publishing Inc.

Berryman, M., Nevin, A., Soohoo, S., \& Ford, T. (2015b). Relational and responsive inclusion: Contexts for becoming and belonging. New York: Peter Lang Publishing.

Berryman, M., Soohoo, S., \& Nevin, A. (2013). Culturally responsive methodologies. Bingley, UK: Emerald Books.

Biddulph, F., Biddulph, J., \& Biddulph, C. (2003). The complexity of community and family influences on children's achievement in Aotearoa New Zealand: Best evidence synthesis. . Wellington : Ministry of Education .

Bishop, R., \& Berryman, M. (2006). Culture speaks: Cultural relationships and classroom learning. Wellington: Huia Publishers.

Bishop, R., Berryman, M., \& Wearmouth, J. (2014). Te Kotahitanga: Towards effective education reform for indigenous and other minoritised students. Wellington: NZCER Press.

Carrington, S., \& MacArthur, J. (2012). Teaching in inclsuive school communities. Milton, Queensland: John Wiley and Sons. 
Chiu, M. M., Chow, B. W. Y., McBride, C., \& Mol, S. T. (2016). Students' sense of belonging at school in 41 countries: Cross-cultural variability. Journal of Cross-Cultural Psychology, 47(2), 175-196.

Durie, M. (2014). Engagement with rangatahi [power point slides]. Presentation to the Palmerston North Youth Sector Network. Retrieved from www.yoss.org.nz/user/file/61/Durie\%20 Youth\%20Engagement.pdf

Finn, J. (1989). Withdrawing from school. Review of Educational Research, 59, 117-142.

Gillborn, D. (2008). Racism and education: Coincidence or conspiracy? . New York: Routledge.

Gonzalez, R., \& Padilla, A. M. (1997). The academic resilience of Mexican American high school students. Hispanic Journal of Behavioral Sciences, 19, 301-317.

Goodenow, C. (1993). Classroom belonging among early adolescent students: Relationships to motivation and achievement. the Journal of Early Adolescence, 13(1), 21-43.

Johnson, M. K., Crosnoe, R., \& Elder, G. H. (2001). Students' attachment and academic engagement: The role of race and ethnicity . Sociology of Education, 74, 318-340.

Lee, S. A. (2005). Up against Whiteness: Race, school and immigrant youth. New York: Teachers College Press.

Lee, S. A. (2011). Unraveling the "model minority" stereotype: Listening to Asian American youth. New York: Teachers College Press.

Leonardo, Z. (2010). Race, Whiteness and education. New York: Routledge Press Ltd.

May, S., Flockton, J., \& Kirkham, S. (2016) PISA 2015: New Zealand Summary Report. Comparative Education Research Unit, Ministry of Education

Ministry of Education. (2007). The New Zealand Curriculum. Wellington: Ministry of Education.

Ministry of Education. (2010). Inclusive Education: Guide for Schools. Retrieved August 3, 2017, from About Inclusive Education: : http://inclusive.tki.org.nz/about-inclusiveeducation/

Ministry of Education. (2015, August 24). The Māori Education Strategy Ka Hikitia. Retrieved from Ministry of Education: http://www.education.govt.nz/ministry-ofeducation/overall-strategies-and-policies/the-maori-education-strategy-ka-hikitiaaccelerating-success-20132017/strategy-overview

Ministry of Education (2016) Ambitious for New Zealand: the Ministry of Education four year plan 2016 - 2020. Wellington: Ministry of Education

Ministry of Education. (2017). Te Whāriki: He whāriki mātauranga mō ngā mokopuna o Aotearoa - Early childhood curriculum. Wellington: Ministry fo Education.

Mitchell, L., \& Cubey, P. (2003). Best evidence synthesis: Characteristics of professional development linked to enhanced pedagogy and children's learning in early childhood settings. Wellington: Ministry of Education. Wellington : Ministry of Education. 
Murphy, M., \& Zirkel, S. (2015). Race and belonging in school: How anticipated and experienced belonging affect choice, persistence, and performance . Teachers College Record, 117(120304), 1-40.

Ministry of Education (2017), PISA 2015: New Zealand students' wellbeing report. Wellington, New Zealand: Ministry of Education.

Roser, R. M., Midgely, C., \& Urdan, T. (1996). Perceptions of the school psychological environment and early adolescents' psychological and behavioral functioning in school: The mediating role of goals and belonging. Journal of Educational Psychology, 88, 404-422.

Steele, C. M., Spencer, S. J., \& Aronson, J. (2002). Contending with group image: The psychology of stereotype and social identity threat. In M. P. Zanna, Advances in experimental social psychology (pp. 379-440). San Diego: Academic Press.

Strahan, D., Smith, T. W., McElrath, T. W., \& Toole, C. M. (2001). Profiles in caring: Teachers who create learning communities in their classrooms. Middle School Journal, 33(1), 41-47.

Sue, D. W., Capodilupo, C. M., Torino, G. C., Bucceri, J. M., Holder, A. M. B., Nadal, K. L., \& Esquilin, M. (2007). Racial microaggressions in everyday life: Implications for clinical practice. American Psychologist, 62(4), 271-286.

Timperley , H., Fung, I., Wilson, A., \& Barrar, H. (2006). Professional Learning and Development: A best evidence synthesis of impact on student outcomes. . San Francisco: American Educational Research Association.

TIMSS \& PIRLS International Study Center. (2016) TIMSS 2014/15 Science Year 9: Trends over 20 years in TIMSS Chestnut Hill, MA: Boston

UNICEF Office of Research (2017). 'Building the Future: Children and the Sustainable Development Goals in Rich Countries', Innocenti Report Card 14, UNICEF Office of Research - Innocenti, Florence.

Wallace, T. L., Ye, F., \& Chhuon, V. (2012). Subdimensions of adolescent belonging in High School. Applied Developmental Science, 16(3), 122-139.

Walton, G. M., \& Cohen, G. C. (2007). A question of belonging: Race, social fit, and achievement. Journal of Personality and Social Psychology, 92(1), 82-96.

Walton, G. M., \& Cohen, G. L. (2011). A brief social-psychological intervention improves academic and health outcomes of minority students. Science, 331(6023), 1447-1451.

Walton, G., Cohen, G., Cwir, D., \& Spencer, S. (2011). Mere belonging: The power of social connections. Journal of personality and social psychology, 102(3), 513-532.

Watson, C. (2005). Classrooms as learning communities: a review of research. . London Review of Education, 3(1), 47-64.

Willms, J. D. (2003). Student engagement at school: A sense of belonging and participation. Paris: Organisation for Economic Cooperation and Development. 